\title{
Proteolytic Degradation of Silk Fibroin Scaffold by Protease XXIII
}

\author{
Prasong Srihanam ${ }^{*, a}$ and Wilaiwan Simchuer ${ }^{\mathrm{b}}$
}

${ }^{a}$ Department of Chemistry; ${ }^{b}$ Central Instrument Unit, Faculty of Science, Mahasarakham University, 44150 Thailand

\begin{abstract}
Two-dimensional silk scaffolds were directly spun on the glass plates by Bombyx mori (called locally NangLai) silkworms and used as subject for proteolytic degradation study with protease XXIII. The silk scaffolds were incubated with enzyme solution at $37^{\circ} \mathrm{C}$ up to 10 weeks. Those of the scaffold properties: surface morphology, secondary structure, mass loss, degradation ratios and particle sizes were investigated. Silk fibroin scaffolds slightly changed of their structure after exposure to the protease. They were also loose of mass greater than $20 \%$ at the end of enzyme incubation periods. Much degradation of the scaffolds was quickly during the 4 weeks and scattering of the particle sizes between 1 to $15 \mu \mathrm{m}$ were found. The results suggested that protease XXIII is an enzyme which could be degraded of the silk fibroin. Therefore, it will be used this enzyme as model study or for preparing silk material for further applications.
\end{abstract}

Keywords: Silk scaffold, enzymatic activity, degradation, material.

\section{INTRODUCTION}

Degradation behaviors of scaffold act an important role in the engineering process of a new tissue [1]. The degradation rate is also considered since it affects on cell activities such as cell viability, cell growth and host cell response [2]. Degradation of materials both synthetic $[3,4]$ and natural [57] polymers have been explored.

Many biomaterials have been studied for load-bearing applications. The results found that rapidly degrading polymers have been shown to transfer load-bearing responsibility but insufficient of mechanical properties [8,9], while nondegradable materials failed to support tissue ingrowth as results of stress shielding in high load-bearing [10, 11]. Therefore integrity was noted an essential factor that resulting in failure of tissue repair [12].

Present study has been focused on the development of silk fibroin (SF) protein scaffold which is a biocompatible and unique mechanical property [1,13-15]. SF is a natural insoluble protein in water as well as in organic solvents, when used as scaffold, results a biomaterial with excellent mechanical properties and slow degradation [16]. The SF has been explored for an extended variety of biomedical applications [17-20].

For SF degradation, enzymatic experiments have been reported [7]. It is known that protease enzymes such as protease XIV [7], chymotrypsin [21], protease XXI [22] or protease $\mathrm{E}$ [23] are capable of degrading SF fibers. In addition, other enzymes such as actinase and carboxylase have been used for degrading SF as food additives, medicines, cosmetics as well as raw material [24-25]. However, proteolytic degradation of SF by protease XXIII was rarely published.

In the present study, silk fibroin scaffolds were prepared for in vitro degradation with protease XXIII. The morphol-

*Address correspondence to this author at the Department of Chemistry, Faculty of Science, Mahasarakham University, 44150 Thailand; Tel: +6643-754246; Fax: +66-43-754246; E-mail: prasong.s@msu.ac.th ogy, secondary structure and quantity of particle losses after exposure to the enzyme were evaluated. The data were compared to previously report to assess the possibility of this enzyme both as model study and for preparation of silk fibroin material.

\section{MATERIALS AND METHODOLOGY}

Materials

Silk

Bombyx mori (B. mori) silkworms were kindly supplied from Silk Innovation Center (SIC), Mahasarakham University, Thailand.

\section{Enzyme}

Enzyme used in this study is protease XXIII which was purchased from Sigma (St. Louis, MO). All other chemicals were analytical grade obtained commercially.

\section{Methodology}

\section{Preparation of Silk Fibroin Scaffolds}

The $5^{\text {th }}$ instar at day 7 of B. mori (called locally NangLai) silkworms were placed on $9 \mathrm{~cm}$ diameters glass plates at room temperature $\left(25-28{ }^{\circ} \mathrm{C}\right)$ to spin fibers. It taken of 15 hour/1 layer/silkworm covered area of the glass plate. Firstly, the 1 layer was prepared and other was sequentially made layer by layer by replacing with new silkworm for each extra layer until obtain 3 layers of raw silk scaffolds (RSS). The RSS were then degummed twice with $0.2 \%$ (w/v) $\mathrm{NaHCO}_{3}$ solution at $90{ }^{\circ} \mathrm{C}$ for $30 \mathrm{~min}$, and rinsed with distilled water to obtain silk fibroin scaffolds (SFS).

\section{Enzyme Assay}

Proteolytic activity was determined by the method of Fogarty and Griffin [26]. Briefly, 2.5\% (w/v) solution of azo-casein was prepared in $0.02 \mathrm{M}$ tris-(hydroxyl methyl) aminomethane (Tris)-hydrochloride buffer, $\mathrm{pH}$ 7.0. After equilibration in a water bath at $37^{\circ} \mathrm{C}$, a $0.2 \mathrm{ml}$ of enzyme solution was added to $1.0 \mathrm{ml}$ of the azo-casein solution. The 
enzymatic reaction was stopped after incubation for $30 \mathrm{~min}$ with $8.0 \mathrm{ml}$ of $0.5 \%$ (w/v) trichloroacetic acid (TCA). The mixture was filtered through a Whatman no. 1 filter paper after standing for $10 \mathrm{~min}$. A $0.5 \mathrm{ml}$ of $0.5 \mathrm{~N} \mathrm{NaOH}$ was added to $5.0 \mathrm{ml}$ of the filtrate, and the color intensity was measured at $440 \mathrm{~nm}$. TCA and substrate without enzyme solution was used as blank. One unit of activity was defined as the activity which caused an increase in optical density (OD) of $0.1 \mathrm{OD}$ unit $/ \mathrm{ml}$ of enzyme under the conditions of the test.

\section{Scanning Electron Microscopy (SEM)}

The scaffolds were sputter-coated with gold and the visualized using scanning electron microscopy (SEM, JEOLJSM 6460LV, Japan).

\section{Secondary Structure Analysis}

Attenuated total reflection infrared spectroscopy (ATRIR, Perkin Elmer-Spectrum Gx, USA) with resolution of 2 $\mathrm{cm}^{-1}$ and 32 scans was used for secondary structural studies.

\section{Degradation of SFS In Vitro}

The SFS $(1 \times 1 \mathrm{~cm}, \mathrm{~N}=3$ per group and time point $)$ were incubated at $37{ }^{\circ} \mathrm{C}$ in $2 \mathrm{ml}$ solution of $1.0 \mathrm{mg} / \mathrm{ml}$ protease XXIII in phosphate buffer saline (PBS) or in PBS as a negative control. Enzyme solution was changed and collected daily. Degradation ratio and wet/dry ratio of the SFS after different periods of degradation was calculated. The degradation ratio and wet/dry ratio were defined as previously reported [1]:

$$
\text { initial dry weight - dry weight after degradation }
$$

degradation ratio $=$

$$
\text { initial dry weight }
$$

wet weight after degradation

wet/dry weight ratio $=$

dry weight after degradation

\section{Mass Loss}

Each weekly, the incubated SFS were prepared following the previously reported [5]. Briefly, the SFS were washed at $90{ }^{\circ} \mathrm{C}$ for $30 \mathrm{~min}$ in $0.3 \%$ detergent and $0.02 \mathrm{M} \mathrm{Na}_{2} \mathrm{CO}_{3}$ to remove protease XXIII. Samples were agitated twice during washing to maintain detergent suspension. Each sample was then rinsed with distilled water and blotted dry on clean towel until dried. The SFS were dried completely in a vacuum oven at $55^{\circ} \mathrm{C}$ for 3 hours. The samples were removed immediately from the oven; they were then massed and returned to new enzyme solution. Percentage of mass loss overtime was determined.

\section{Particle Size Analysis}

The solutions were gathered every 24 hours intervals over 70 days and $1 \mathrm{ml}$ of each sample were kept at $-20{ }^{\circ} \mathrm{C}$. The sample from each weekly interval time was pooled and then analyzed using particle size analyzer (LS Particle size analyzer, Beckman Coulter LS 230).

\section{RESULTS AND DISCUSSION}

\section{SEM Observation}

The silk scaffolds prepared by directly spinning of silkworm shown in Fig. (1). They composed with high porosity,

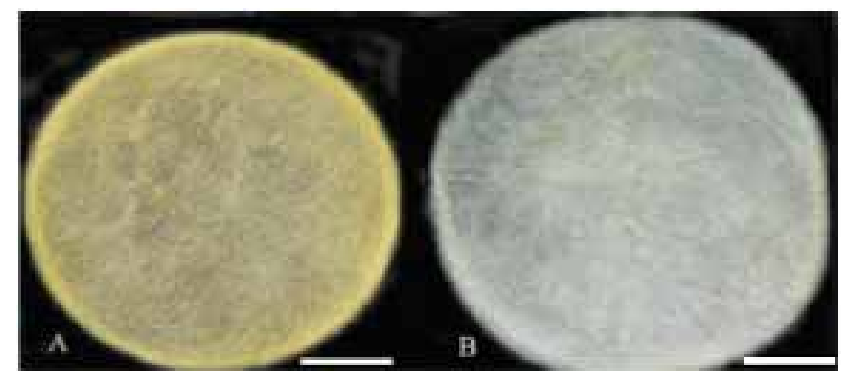

Fig. (1). SEM images of SFS before (A) and after (B) removing of sericin. $($ Bars $=1 \mathrm{~cm})$.

large pore sizes and moderate of surface area since they arranged in micro-fibers. The morphological surfaces of the SFS after incubating with enzyme solution were observed under SEM (Fig. 2). The surfaces of the silk fibers before enzymatic degradation were smooth, homogeneously appearances. During degradation for 1 to 10 weeks, rough on the silk fibers was increased gradually. The results indicated that the fracture of the silk fiber surfaces caused from exposure of the silk surfaces to the protease XXIII. The changes of the fibers exposed most on the surfaces area. The activity of protease XXIII was also tested by using azo-casein which suitable as substrate for proteolytic enzymes. It is chromogenic substrate and could be digested by the protease, which are soluble in TCA and determined in the range 366 to $450 \mathrm{~nm}$. The activity of protease XXIII showed consistence level up to 14 days, then dramatically decreased until 21 days. However, the activity was still detected even 7 weeks but almost lost activity after incubating for 8 weeks (Fig. 3).
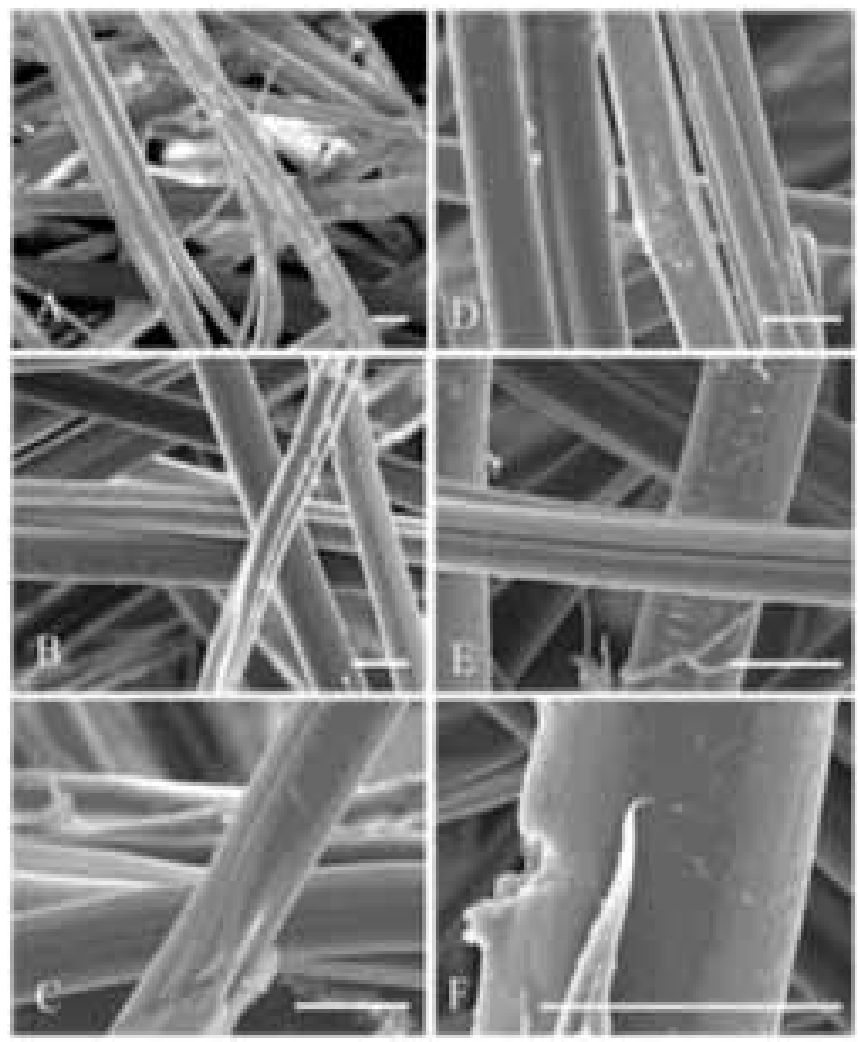

Fig. (2). SEM images of SFS after protease incubating in different periods: (A) 1 week, (B) 3 weeks, (C) 4 weeks, (D) 5 weeks, (E) 6 weeks, $(\mathbf{F}) 7$ weeks. $($ Bars $=8 \mu \mathrm{m})$. 


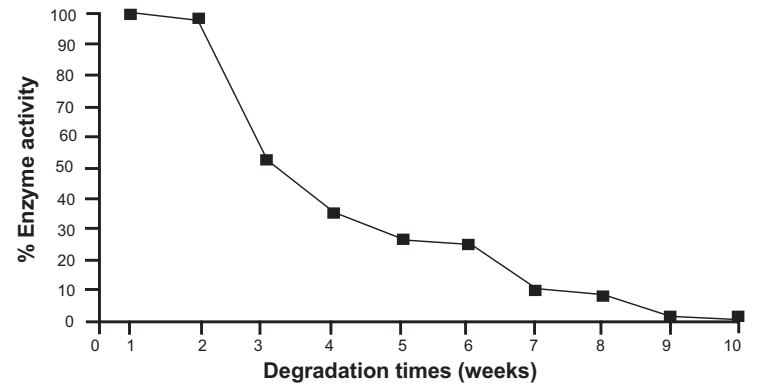

Fig. (3). Activity lost of protease XXIII after incubating with SFS.

\section{ATR-IR Spectra}

Generally, silk fibroin structure before degradation is coexisted of random coil and predominant $\beta$-sheet structure [5]. The structure of the SFS immersed in protease XXIII solution was changed slightly as did not in PBS (Fig. 4). However, over 70 days of incubation, no dramatically changed was observed. The results showed similar with previously reported [5], since the amide I band $\left(1628 \mathrm{~cm}^{-1}\right)$ did not shift by the digestion time while the peak of amide II $\left(1545 \mathrm{~cm}^{-1}\right)$ was a slight decrease when incubation time increased. The findings show that the silk I structure was easily formed during exposure to protease XXIII because of the resulting break of peptide bonds of silk amino acids.

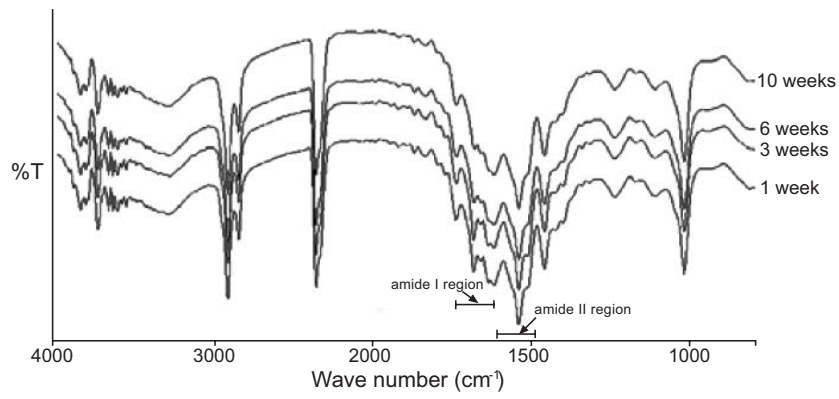

Fig. (4). ATR-IR spectra of SFS after degradation with protease XXIII in different periods.

\section{Mass Loss}

Mass loss is one of the parameter to investigate the organized geometry of the silk fibers. After 6 weeks of proteolytic degradation, greater than $20 \%$ loss in mass was ob-

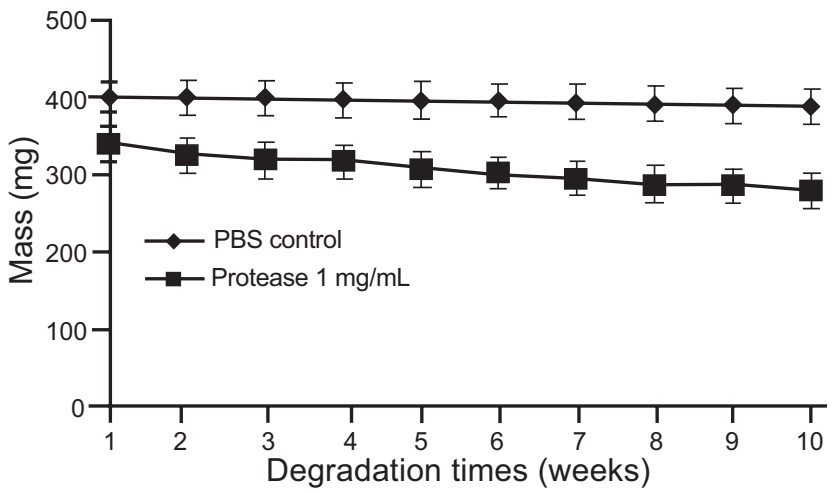

Fig. (5). Mass lose profile of SFS after incubating with protease XXIII compared to PBS. served, but not for PBS incubated samples (Fig. 5). The findings were related to the studied of Horan et al. [5]. The degradation rate was quickly during the initial $1-2$ weeks that reflects a drop in silk mass. Li et al. [7] demonstrated that protease could be cleaved silk non-discriminately. In addition, Horan et al. [5] also reported that increasing fragmentation of silk fibroin was present within 7 days of protease incubation. However, it is an important to note that silk fibroin is mechanically robust biomaterial with long-term degradation characteristics.

\section{Degradation Ratio}

The degradation ratio of SFS after enzymatic degradation in vitro shows in Fig. (6). The result found that the SFS degraded quickly at the first 2 weeks and about $20 \mathrm{wt} \%$ of the original weight loss was obtained. The degradation rate decreased when the time of the incubation increased. After 4 weeks, $20 \mathrm{wt} \%$ of the original weight loss was obtained. In addition, $\sim 25 \mathrm{wt} \%$ of the original weight loss was detected after degradation for 10 weeks.

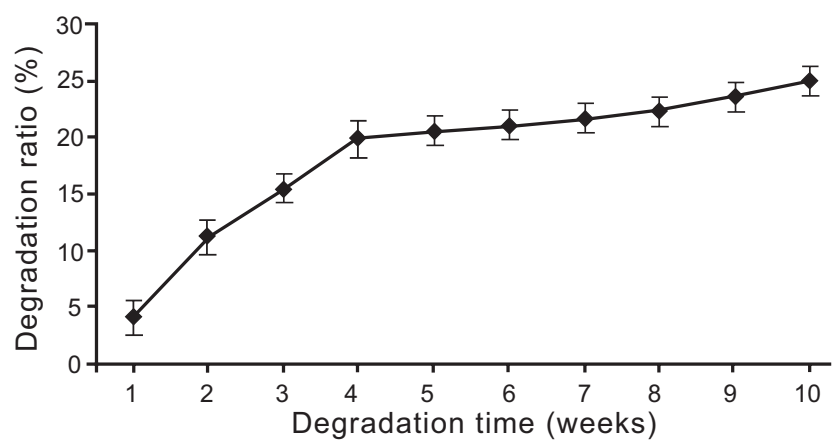

Fig. (6). Degradation ratio of SFS during degradation with protease XXIII solution.

\section{Wet/Dry Weight Ratio}

Fig. (7) shows wet/dry weight ratio of the SFS during 10 weeks of in vitro degradation. The wet/dry weight ratio fluctuates in range from 18.57 to 21.34 . The result suggested that the SFS's swelling property is very stable. According to the silk fibroin is a hydrophilic biomaterial, it reveal hydrophilicity absorb water and thus degrade by cleavage of hydrolytically peptide bonds. This hydrophobicity gives rise to the large wet/dry weight ratio and the degradation process affects little the swelling property [1].

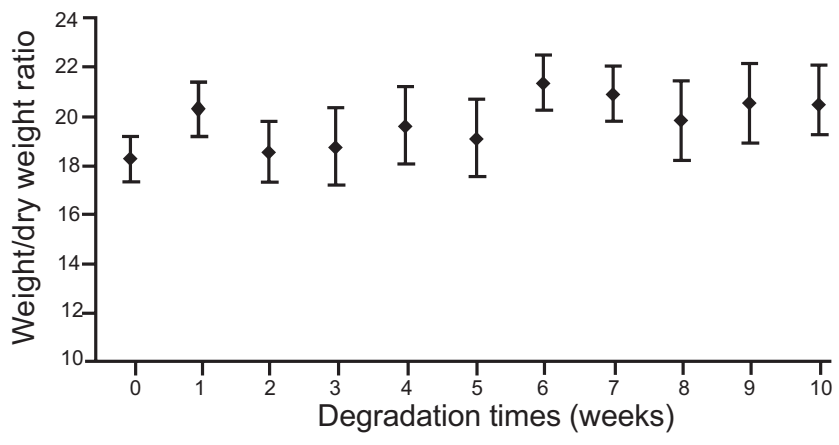

Fig. (7). Wet/dry weight ratio of SFS during degradation with protease XXIII solution. 


\section{Particle Size Analysis}

Particle sizes of the SFS after incubation with protease XXIII shown in Fig. (8). It was found that the particle sizes were arranged from 1 to $15 \mu \mathrm{m}$, being highest no. of $3 \mu \mathrm{m}$. The debris particles may have attached to the silk surface or bound together by protease absorbed [5]. However, some debris was removed away during processing by water or solution. The particles cleaved from the silk fiber and within the enzyme solution remained therefore a maximum 1 day. Therefore, the sizes of particles should be decreased over time when increased of the rate of mass loss. This may be thought that the increased in exposed surface area on fractured fibers provided additional sites for enzymatic attack on silk [5].

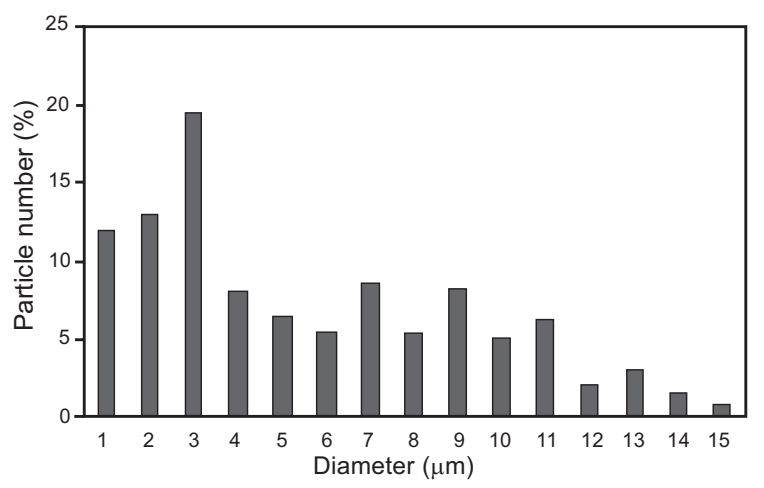

Fig. (8). Particle sizes distribution of SFS after exposure to protease XXIII by particle analyzer.

\section{CONCLUSION}

The enzymatic function of protease XXIII on the SFS has been evidenced. The results indicate that the protease XXIII has an ability to degrade the SFS. The silk fibroin fiber was shown to proteolytically degrade those of mass loss, particle sizes or swelling ratio. It is promising that protease XXIII could be used as model for degradation study of silk fibroin. However, an understanding in the degradation of silk fibroin by protease XXIII should be clarified as an alternative proteolytic enzyme.

\section{ACKNOWLEDGEMENTS}

We thank the Department of Chemistry, and Central Instrument Unit, Faculty of Science, Mahasarakham University for facility supporting. We also thank to the staff of Silk Innovation Center, Mahasarakham University for providing of silkworms.

\section{REFERENCES}

[1] She, Z.; Zhang, B.; Jin, C.; Feng, Q.; Xu, Y. Preparation and in vitro degradation of porous three-dimensional silk fibroin/chitosan scaffold. Polym. Degrad. Stab., 2008, 93(7), 1316-1322.

[2] Yang, F.; Cui, W.J.; Xiong, Z.; Liu, L.; Bei, J.Z.; Wang, S.G. Poly(L,L-lactide-co-glycolide)/tricalcium phosphate composite scaffold and its various changes during degradation in vitro. Polym. Degrad. Stab., 2006, 91(12), 3065-3073.

[3] Derestani Farahani, T.; Akbar Entezami, A.; Mobedi, H.; Abtahi, M. Degradation of Poly(D,L-lactide-co-glycolide) 50:50 Implant in aqueous medium. Iran. Polym. J., 2005, 14(8), 753-763.
Hakkarainen, M.; Albetsson, A.C.; Karlsson, S. Weight losses and molecular weight changes correlated with the evaluation of hydroxyl-acids in simulated in vivo degradation of homo- and copolymers of PLA and PGA. Polym. Degrad. Stab., 1996, 52(3), 283-291.

[5] Horan, R.L.; Antle, K.; Collette, A.L.; Wang, Y.; Huang, J.; Moreau, J.E.; Volloch, V.; Kaplan, D.L.; Altman, G.H. In vitro degradation of silk fibroin. Biomaterials, 2005, 26(17), 3385-3393.

[6] Zhang, H.; Neau, S.H. In vitro degradation of chitosan by bacterial enzymes from rat cecal and colonic contents. Biomaterials, 2002, 23(13), 2761-2766.

[7] Li, M.; Ogiso, M.; Minoura, N. Enzymatic degradation behavior of porous silk fibroin sheets. Biomaterials, 2003, 24(2), 357-365.

[8] Durselen, L.; Dauner, M.; Hierlemann, H.; Planck, H.; Claes, L.E.; Ignatius, A. Resorbable polymer fibers for ligament augmentation. J. Biomed. Mater. Res., 2001, 58(6), 666-672.

[9] Lu, L.; Peter, S.J.; Lyman, M.D.; Lai, H.L.; Leite, S.M.; Tamada, J.A.; Uyama, S.; Vacanti, J.P.; Langer, R.; Mikos, A.G. In vitro and in vivo degradation of porous poly(D,L-lactic-co-glycolic acid) foams. Biomaterials, 2000, 21(18), 1837-1845.

[10] Richmond, J.C.; Manseanu, C.J.; Patz, R.; McConville, O. Anterior cruciate ligament reconstruction using a Dacron prosthesis. A long term study. Am. J. Sports Med., 1992, 20(1), 24-28.

[11] Kumar, K.; Maffulli, N. The ligament augmentation device. An historical perspective. Arthroscopy, 1999, 15(4), 422-432.

[12] Frank, B.C.; Jackson, D.W. The science of reconstruction of the anterior cruciate ligament. J. Bone Joint Surg. Am., 1997, 79(10), 1556-1576.

[13] Kim, H.J.; Kim, U.-J.; Kim, H.S.; Li, C.; Wada, M.; Leisk, G.G.; Kaplan, D.L. Bone tissue engineering with premineralized silk scaffolds. Bone, 2008, 42(6): 1226-1234.

[14] Lin, F.; Li, Y.; Jin, J.; Cai, Y.; Wei, K.; Yao, J. Deposition behavior and properties of silk fibroin scaffolds soaked in simulated body fluid. Mater. Chem. Phys., 2008, 111(1), 92-97.

[15] Uebersax, L.; Merkle, H.P.; Meinel, L. Insulin-like growth factor I releasing silk fibroin scaffolds induce chondrogenic differentiation of human mesenchymal stem cells. J. Control. Release, 2008, 127(1), 12-21.

[16] Meinel, L.; Hofmann, S.; Karageorgiou, V.; Kirker-Head, C; McCool, J.; Gronowicz, G.; Zichner, L.; Langer, R.; VunjakNovakovic, G.; Kaplan, D.L. The inflammatory responses to silk films in vitro and in vivo. Biomaterials, 2005, 26(2), 147-155.

[17] Wang, X.; Wenk, E.; Hu, X.; Castro, G.R.; Meinel, L.; Wang, X.; Li, C.; Merkle, H.; Kaplan, D.L. Silk coatings on PLGA and alginate microspheres for protein delivery. Biomaterials, 2007, 28(28), 4161-4169.

[18] Kim, U.J.; Park, J.; Kim, H.J.; Wada, M.; Kaplan, D.L. Threedimensional aqueous-derived biomaterial scaffolds from silk fibroin. Biomaterials, 2005, 26(15), 2775-2785.

[19] Wang, Y.; Kim, U.-J.; Blasioli, D.J.; Kim, H.J.; Kaplan, D.L. In vitro cartilage tissue engineering with $3 \mathrm{D}$ porous aqueous-derived silk scaffolds and mesenchymal stem cells. Biomaterials, 2005, 26(34), 7082-7094.

[20] Altman, G.H.; Diaz, F.; Jakuba, C.; Calabro, T.; Horan, R.L.; Chen, J.; Lu, H.; Richmond, J.; Kaplan, D.L. Silk-based biomaterials. Biomaterials, 2003, 24(3), 401-416.

[21] Tsukada, M. Effect of $\alpha$-chymotrypsin on the structure of silk fibroin. J. Seric. Sci. Jpn., 1986, 55, 126-130.

[22] Arai, T.; Freddi, G.; Innocenti, R.; Tsukada, M. Biodegradation of Bombyx mori silk fibroin fibers and films. J. Appl. Polym. Sci., 2004, 91(4), 2383-2390.

[23] Minoura, N.; Tsukada, M.; Nagura, M. Physico-chemical properties of silk fibroin membrane as a biomaterial. Biomaterials, 1990, 11(6), 430-434. 
[24] Chen, K.; Umeda, Y.; Hirabayashi, K. Enzymatic hydrolysis of silk fibroin. J. Seric. Sci. Jpn., 1996, 65, 131-133.

[25] Chen, G.; Arai, M.; Hirabayashi, K. Isolation of tyrosine from silk fibroin by enzyme hydrolysis. J. Seric. Sci. Jpn., 1996, 65, 182184.
[26] Fogarty, W.M.; Griffin, P.J. Production and purification of the metalloprotease of Bacillus polymyxa. Appl. Microbiol., 1973, 26, 185-190

(C) Srihanam and Simchuer; Licensee Bentham Open

This is an open access article licensed under the terms of the Creative Commons Attribution Non-Commercial License (http://creativecommons.org/licenses/by-nc/3.0/) which permits unrestricted, non-commercial use, distribution and reproduction in any medium, provided the work is properly cited. 